\title{
A new species of Caridina H. Milne Edwards, 1837 (Family: Atyidae) from a limestone cave on Interview Island, Andaman and Nicobar Islands, India
}

\author{
JAYACHANDRAN KUNJURAMAN VIJAYAMMA ${ }^{1}$, AMRUTA DHAMORIKAR ${ }^{2,3,5}$ \& SHIRISH MANCHI ${ }^{2,4}$ * \\ ${ }^{1}$ Kerala University of Fisheries and Ocean Studies, Kochi 682 506, Kerala, India.

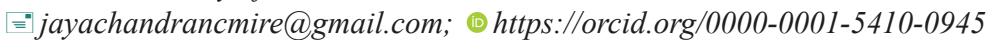 \\ ${ }^{2}$ Sálim Ali Centre for Ornithology and Natural History, Coimbatore, Tamil Nadu, India. \\ ${ }^{3}$ ఏ"ahdhamorikar@gmail.com; — https://orcid.org/0000-0002-0213-3195 \\ ${ }^{4}$ ఏ" ediblenest@gmail.com; — https://orcid.org/0000-0002-7540-2616 \\ ${ }^{5}$ Speleological Association of India, Coimbatore, Tamil Nadu, India \\ "Corresponding author. !" ediblenest@gmail.com
}

\begin{abstract}
Caridina ravisankarani sp. nov. is a cave-adapted species, collected during June and November 2018 and January 2019 from a limestone cave (CN2) on Interview Island, Andaman and Nicobar Islands. The shrimps were collected from a stream, sourced through the percolation of rainwater, which reduces during the post-monsoon months. The species is closely related to Caridina typus H. Milne Edwards, 1837, Caridina villadolidi Blanco, 1939 and Caridina jeani Cai, 2010. A detailed comparison of characters and a key for identification are given in the text. The present species can be diagnosed by the presence of: short rostum with edentulous upper margin and ventral margin with 2 minute teeth situated at the distal part; outer antennular flagellum with 16 segments at the basal part swollen; highly atrophied propodus and dactylus of endopod of $2^{\text {nd }}$ maxilliped; bushy long setae on fingers of $2^{\text {nd }}$ chelate legs; dactylus of $5^{\text {th }}$ pereopod with $42-43$ comb-like bristles; dieresis with 18 spines; dorsal surface of telson with 4-5 pairs of spines and disto-median region doesn't end in a point, outer lateral pair of spines absent and eyes with cornea pigmentation variable, from totally absent to a small black spot. Fecundity is 1300 eggs with an average length $0.71 \pm 0.03 \mathrm{~mm}$ and width $0.42 \pm 0.03 \mathrm{~mm}(\mathrm{Mean} \pm \mathrm{SD})$.
\end{abstract}

Key words: Caridina ravisankarani sp. nov., Atyidae, cave fauna, Andaman Islands, Stygobite

\section{Introduction}

Andaman and Nicobar Islands, located in the Bay of Bengal, have humid climatic conditions receiving more than $3000 \mathrm{~mm}$ rainfall per year. With dominating tropical evergreen and semi-evergreen forests, the Island arc possesses 395 limestone caves, of which $62.2 \%$ are situated in the inland area and $37.8 \%$ on the coast (Manchi 2014). Interview Island in the west of the Middle Andaman Islands, the only identified carbonate island, is the largest Wildlife Sanctuary (134 km²) of the archipelago (Kawalkar \& Manchi 2020). This uninhabited and scarcely explored karst island has 34 known limestone caves (Manchi 2014). The present investigation is part of a conservation program for the cave-dwelling Edible-nest Swiftlet (Aerodramus fuciphagus Thunberg, 1812) and also to explore the role of this bird in the cave ecosystem and co-existing fauna. For survey purposes, these caves are identified with the designated cave number (CN) as CN1, CN2, CN3, so on (Sankaran 2001, Manchi 2014).

Epigean crustacean collections in the Andaman Islands, including Interview Islands, were carried out as early as 1911, 1933 \& 1934 by Captain C. G. Rogers and H. S. Rao respectively (Tiwari \& Pillai 1971). The studies have reported a few atyid shrimps, namely, Caridina typus H. Milne Edwards, 1837, Caridina brachydactyla De Man, 1908, Caridina serratirostris De Man, 1892 and Caridina gracilirostris De Man, 1892. However, information on species assemblages in hypogean environments such as caves remains unexplored to date. The authors (AD, SM) have surveyed caves $\mathrm{CN} 1, \mathrm{CN} 2, \mathrm{CN} 3$ and atyid shrimps only from $\mathrm{CN} 2$ cave of Interview islands during the present study. On analysis, it was found to possess specific characters of its own and distinctly differs from $C$. typus. Hence, it is described herein as a new species and this forms the first report of atyid shrimps from the cave. Surveys were also done in epigean waters in search of this species but were not found. 


\section{Materials and methods}

The samples were collected from shallow pools of the cave identified as CN2 of Interview Island $\left(12^{\mathrm{O}} 52^{\prime} 51.12^{\prime}\right.$, $\left.92^{\circ} 41^{\prime} 42.32^{\prime \prime} \mathrm{E}\right)$, with a maximum depth of $0.2 \mathrm{~m}$ during June 2018, November 2018 and January 2019. Nature of the cave, pools within the cave and collection sites of specimens are given in Fig. 3A, B, C, D to understand the peculiarity of caves. Specimens were collected with the help of a $15 \mathrm{ml}$ circular tube with $25 \mathrm{x} 57 \mathrm{~mm}$ size. The collection tube was placed in the opposite direction of the streamflow. With the help of a headlamp, the shrimps were guided into the collection tubes and collected with forceps. Ten specimens were collected for identification, of which three were utilized for study, and the rest were released back into the pool. The samples were preserved in 99\% ethanol. The holotype was deposited in the Referral Museum of Central Marine Fisheries Research Institute (ICAR-CMFRI), Kochi, India (Accession Number - CMFRI DNR No. 2.3.3.2). The status of the present species has been confirmed by consulting relevant literature (H. Milne Edwards 1837, de Haan 1849, de Man 1892, 1908, Ortmann 1894, Bouvier 1904, 1905, 1925, Edmondson 1935, Blanco 1939, Holthuis 1969, Tiwari \& Pillai 1971, Choy 1984, Short 1993, Choy \& Marshall 1997, Cai 2010). Surveys from epigean waters did not encounter this species.

\section{Taxonomy}

\section{Family : Atyidae De Haan, 1849}

\section{Genus : Caridina H. Milne Edwards, 1837}

\section{Species : Caridina ravisankarani sp.nov. \\ Materials examined}

Measurements. Holotype male: $\mathrm{tl}-28 \mathrm{~mm}$; $\mathrm{cl}-9.5 \mathrm{~mm} ; \mathrm{rl}-2 \mathrm{~mm}$; paratypes male $-\mathrm{tl}-24 \mathrm{~mm}$; $\mathrm{cl}-9 \mathrm{~mm}$; rl-2mm; female: tl-23mm; cl-8 mm; rl-1.8 mm.

Description. Rostrum short, slender, shallow, reaching as far as the distal end of basal segment of the antennular peduncle, distal end pointed and directed forwards, upper margin straight edentulous, two-third of proximal ventral margin nearly straight and distal third gently curved, bears two very minute teeth, adrostral carina prominent incomplete, situated at the proximal half at the lower region and divides unequally; carapace smooth, orbit broad, antennal spine prominent, pterygostomian angle broadly rounded (Fig. 1A).

Eyes with cornea pigmentation variable, from totally absent to a small black spot.

The sixth abdominal segment is a little longer than the fifth. Telson broad basally and narrow distally reaches as far as the outer spine of uropodal exopod, disto-lateral margins pointed; upper surface bears 5 pairs of spines, promixal most pair at about one-third distance from the base, distal pair subdistal in position; disto-median part not spinous, distal region bears 8 long spines and without short spines, outermost pair with setae only on the inner side, remaining bipectinate, the base of each spine with chitinous structures (Fig. 1B, C).

Antennular peduncle reaches beyond the level of outer spine of antennal scale, three segments in the ratio 1.00:0.55:0.54; basal segment broad, lateral border ends distally as a characteristic triangular prominence, stylocerite long, sharp and extends as far as $80 \%$ of the proximal segment; middle and distal segments almost equalsized; 16 segments at the proximal part of outer flagellum swollen, characteristic, inner flagellum slightly broad (Fig. 1D). Antennal scale fully developed, 0.38 times broad as long, the outer lateral spine extends to 0.79 times its length, and flagellar peduncle 0.49 times the length of the scale. Incisor process stronger than molar process with one broad, one sharp, and two smaller teeth, molar process with concavity, a series of short stiff closely packed fine setae in between molar and incisor processes; apophysis long and broad (Fig. 1E). Maxillulae with coxa very broad bears a fringe of stiff spinous setae on the inner border, basis also broader with scattered setae, endopod slender. Maxillae with coxa and basis highly flattened with closely set stiff long setae in rows on the inner border, coxa smaller, endopod reduced, and exopod flattened with much elongated setae (Fig. 1F).

First maxilliped with highly flattened short coxa and long broad basis, inner borders with stiff long closely set stiff setae; endopod short, exopod highly flattened and membranous, basal part with a rectangular caridean lobe bearing long setae and a club-shaped distal portion with very long setae at the tip (Fig. 1G). Second maxilliped with endopod reduced in structure, ischium, and merus almost equal-sized, carpus ring-shaped, propodus distally 
expanded and dactylus highly reduced, inner margin of ischium and the distal surface of propodus bear long stiff spinous setae; exopod slender and highly elongated, more than two times longer than endopod and tip bears very long setae (Fig. 2A). Three segments of the third maxilliped in the ratio 35.4:34.3:30.3; distal segment ends in a sharp spine and bears seven spines on distal flexor margin of which distal-most attains the size of the distal spinous part of the segment so that it appears a claw and bunches of plumose stiff long setae along basal 2/3 distance, distal $1 / 3$ with scattered setae, exopod reaches about half of the second segment and with setae on either side distally (Figs. 1H, 2B).

First pereopod stronger than second; Ischium, merus, carpus, propodus, palm, and fingers in the ratio 17.1:25.7: 31.4:47.0:25.7:21.4; distal carpus as broad as palm, distal region highly excavated and longer than merus, propodus longer than carpus; palm swollen, fingers slightly shorter than palm, spoon-shaped with characteristic long setae, bushy along the rim of both fingers (Fig. 2C). Second pereopods slender, ischium, merus, carpus, propodus, and fingers in the ratio 19.0: 27.4: 32.1:21.4:16.2; merus and carpus longer than propodus; fingers longer than palm and its tips with a very long tuft of setae, characteristic to species (Fig. 2D).

Third pereopods with ischium, merus, carpus, propodus, dactylus in the ratio 12.3:32.5:19.5:27.1:8.7; propodus with 11 spinules on flexor margin; dactylus ends in a sharp curved spine and with 4-5 spinules on flexor margin, merus longest (Fig. 2E, F). Fourth pereopods with merus and propodus of almost same size, propodus with 10 minute spinules on flexor margin and dactylus ends in a sharp curved spine and with 7-8 spinules on flexor margin (Fig. $2 \mathrm{H})$. Fifth pereopods with ischium, merus, carpus, propodus, dactylus in the ratio 8.4:28.9:16.9:35.0:10.8; merus with three, propodus with seven spinules on flexor margins and carpus with one distal spine; dactylus longer than ischium and ends in a sharp curved spine and with 42-43 bristle setae, propodus longest (Fig. 2G).

Pleopods. Female: first pleopods more pediform, basis concave on the inner side, with long stiff setae along margins, exopod flat with scattered stiff setae on free border and endopod modified as in figure (Fig. 2I); male: basis flat, exopod flattened with setae more towards tip, endopod with characteristic finger-shaped appendix interna and tip with stiff setae (Fig. 2J). Second pleopod male: basis slightly broader and bears appendix masculina and appendix interna, appendix interna $1 / 3^{\text {rd }}$ of appendix masculina (Fig. $2 \mathrm{~K}$ ); female: basis leg like with appendix interna (Fig. 2L); remaining pleopods pediform with exopod and endopod and appendix interna; basis as long as or slightly longer than rami and with scattered setae (Fig. 2M). Uropods highly developed, exopod with a sharp spine at 2/3 distance, diaeresis with 18 prominent strong spines (Fig. 1C, I).

Paratypes also possess the same characters described above.

The present species can be identified from the closely related species by the key provided below.

1 Dorsal surface of telson with 5-7 pairs of spines; dactylus of $5^{\text {th }}$ pereopod with $44-77$ prominent setae; dieresis with $16-23$

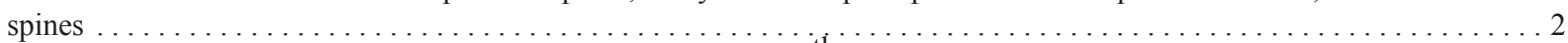

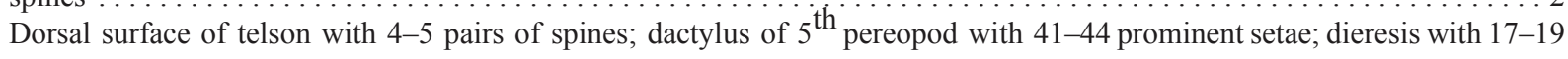

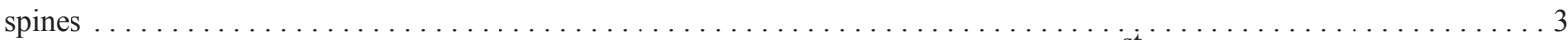
Disto-median region of telson pointed, outer lateral spines short and in-curved; carpus of $1^{\text {st }}$ cheliped equals merus and fingers shorter than palm; dactylus of $5^{\text {th }}$ pereopod with 56-77 spinous setae; rostrum short, upper margin edentulous and ventral

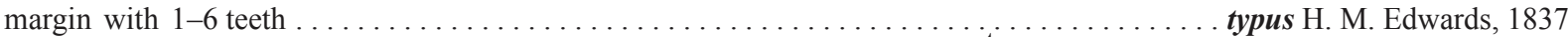
Disto-median region of telson pointed, outer lateral spines short; carpus of $1^{\text {st }}$ cheliped shorter than merus and fingers longer than palm; dactylus of $5^{\text {th }}$ pereopod with 44 spinous setae; rostrum long, upper margin edentulous and ventral margin with 2-8

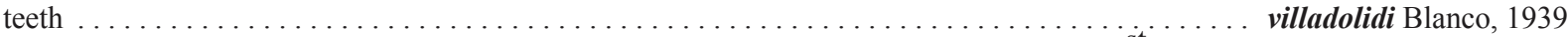
Disto-median region of telson pointed, outer lateral spines short-incurved; carpus of $1^{\text {st }}$ cheliped shorter than merus and fingers longer than palm; dactylus of $5^{\text {th }}$ pereopod with 41-49 spinous setae; rostrum short, upper margin edentulous and ventral margin with 1-5 minute teeth situated at distal part; outer antennular flagellum without swollen basal segments .....

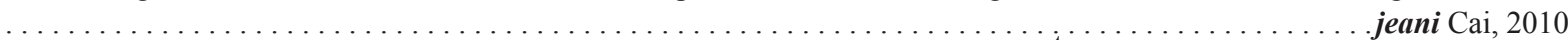
Disto-median region of telson not pointed, outer lateral spines absent; carpus of $1^{\text {st }}$ cheliped longer than merus and fingers shorter than palm; dactylus of $5^{\text {th }}$ pereopod with 42-43 spinous setae; rostrum short, upper margin edentulous and ventral margin with 2 minute teeth situated at distal part; 16 segments at the basal part of outer antennular flagellum swollen.......

ravisankarani sp. nov.

Coloration in life. Male and female both entirely translucent, with mild yellowish spots overall, more on carapace.

Notes on biology. Collection during June and December -January, the deep and shallow pools in the cave were dominated by berried females and probably the peak breeding period. A female collected in June 2018 had as many as 1300 eggs. The eggs $(n=29)$ had an average length of $0.71 \pm 0.03 \mathrm{~mm}($ Mean \pm SD) and a width of $0.42 \pm 0.03$ $\mathrm{mm}$. 


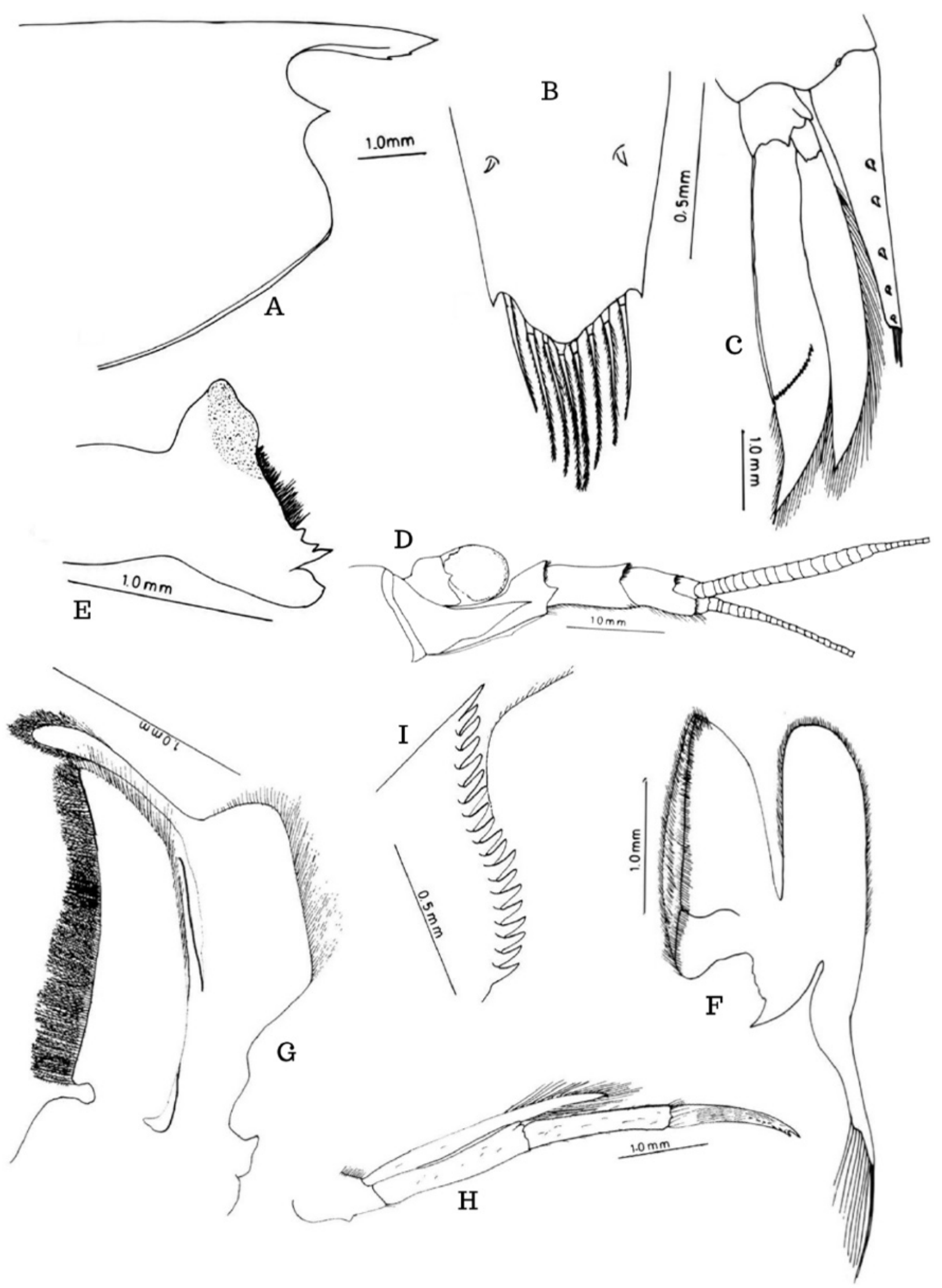

FIGURE 1. A-I : Caridina ravisankarani sp. nov. holotype, A - anterior carapace, B - distal part of telson, C-uropod and telson lateral view, $\mathrm{D}-$ antennule, $\mathrm{E}-$ mandible, $\mathrm{F}-$ maxilla, $\mathrm{G}-1^{\mathrm{st}}$ maxilliped, $\mathrm{H}-3^{\text {rd }}$ maxilliped, $\mathrm{I}-$ dieresis showing spines. 


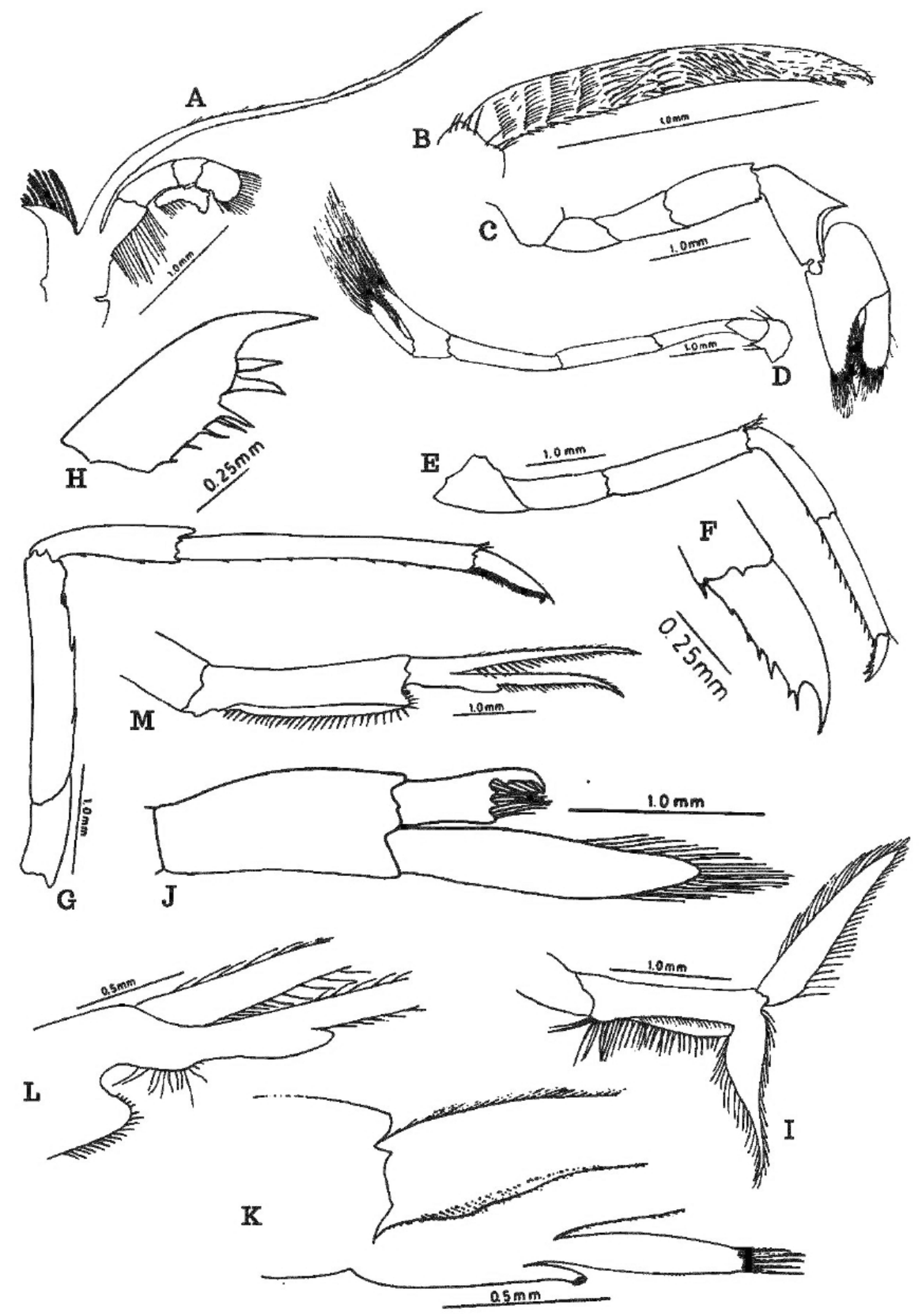

FIGURE 2. A-M : Caridina ravisankarani sp.nov. holotype, $\mathrm{A}-2^{\text {nd }}$ maxilliped, $\mathrm{B}-$ distal segment of $3^{\text {rd }}$ maxilliped showing claw-like tip, $\mathrm{C}-1^{\text {st }}$ pereopod, D-2 ${ }^{\text {nd }}$ pereopod, E- $3^{\text {rd }}$ pereopod, $\mathrm{F}-$ dactylus of $3^{\text {rd }}$ pereopod, $\mathrm{G}-5^{\text {th }}$ pereopod, $\mathrm{H}-$ dactylus of $4^{\text {th }}$ pereopod, $\mathrm{I}-1^{\text {st }}$ pleopod female, $\mathrm{J}-1^{\text {st }}$ pleopod of male, $\mathrm{K}-$ part of $2^{\text {nd }}$ pleopod of male showing appendix masculina and appendix interna, $\mathrm{L}-$ part of $2^{\text {nd }}$ pleopod of female showing appendix interna, $\mathrm{M}-3^{\text {rd }}$ pleopod. 


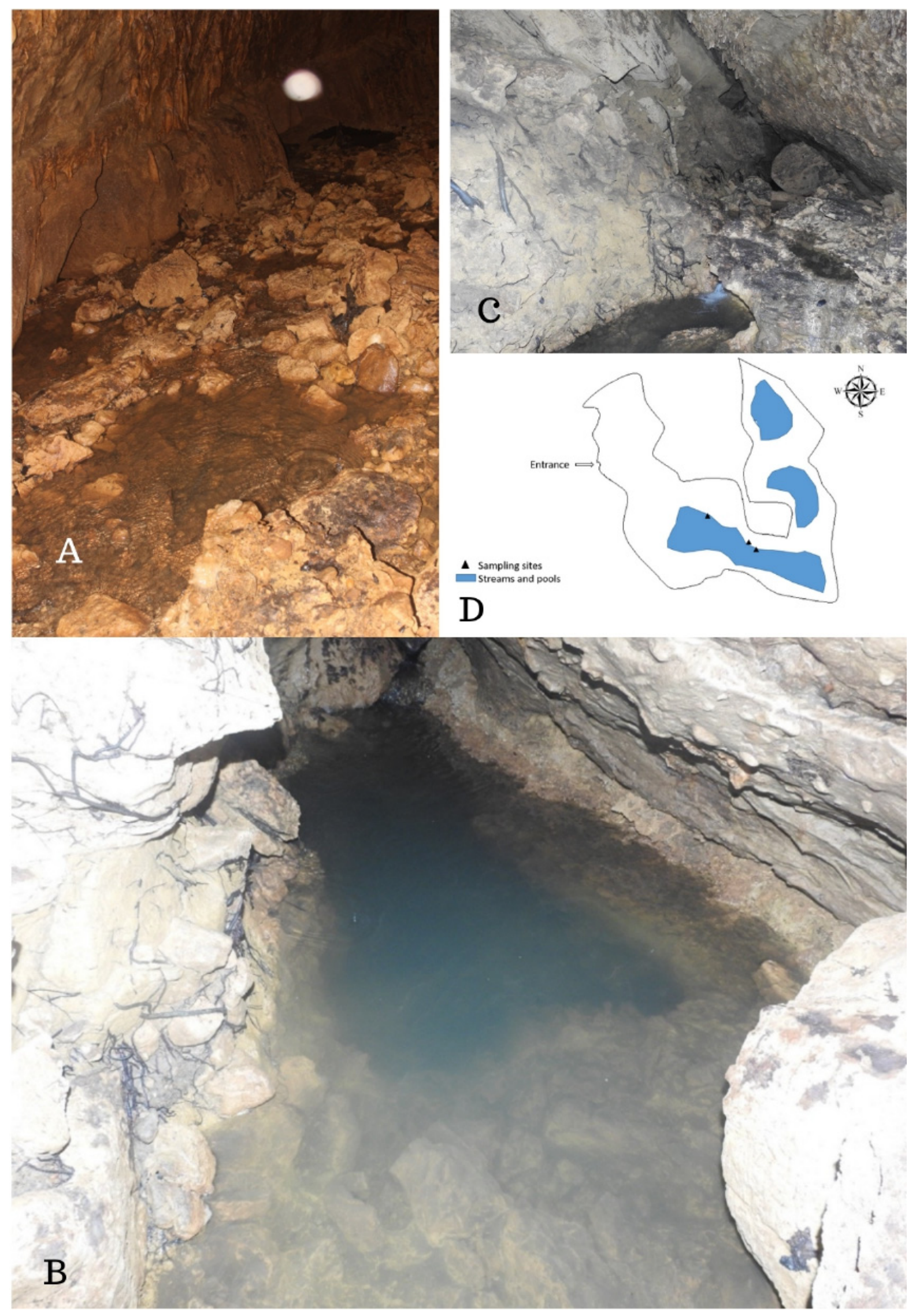

FIGURE 3. A-Stream with intermittent shallow pools across the cave floor, the collection site of Caridina ravisankarani sp. nov., B-deep pool (about $8 \mathrm{~m}$ depth) within the cave beyond which cave is inapproachable, $\mathrm{C}$ - collection site (shallow pool), natural habitat of the shrimp, D-map of the cave depicting sampling sites. 
Distribution. A cave (CN2) on the Interview Island, Andaman and Nicobar Islands, India.

Habitat. CN2, a limestone cave around a kilometre inland from the west coast in the central part of Interview Island, holds underground water (Fig. 3A, B, C). As the primary source of this water is rainwater and its runoff, the stream inside the cave flows during monsoon and post- monsoon periods leaving small pools during the dry season. The stream flows from one end of the cave (south-west) where the gushing water cascades into the deep pools, and towards the mid-section, it splits into streamlets and shallow pools $(0.2 \mathrm{~m}$ depth) and ultimately goes underground at north-west where the cave is raised. The water in the cave travels approximately $20 \mathrm{~m}$ before emptying underground (Figs. 3A, B, C). Except for a small portion near the opening, the entire length of the cave has no light. The water temperature in the cave's sample collection zones was between $25-26^{\circ} \mathrm{C}$. The $\mathrm{pH}$ of the water was between 6.0-7.0. During the sample collection, the air temperature and relative humidity were $24^{\circ} \mathrm{C}$ and $93.2 \%$, respectively. This cave has seasonal deficient oxygen levels, especially during the pre-monsoon (dry) season between March and June. Geologically Interview Island has Archipelago series rock type (Bandopadhyay \& Carter 2017). The significant water source inside caves is through percolation during the monsoon and postmonsoon periods. This percolating water brings in organic matter as an external energy source to form a significant energy supply for the subterranean life in some caves (Culver \& Pipan 2009).

In $\mathrm{CN} 2$, shrimps were found under rocks, boulders, and crevices in the pools $(0.2 \mathrm{~m}$ to $8 \mathrm{~m}$ deep) (Fig. $3 \mathrm{~A}$, $\mathrm{B}, \mathrm{C})$. The presence of various sized individuals during the visits and no signs of their presence in the epigean water bodies indicate it being restricted to the hypogean habitats. Being photophobic, these shrimps quickly darted in the opposite direction when exposed to the light source. Some other shrimps and amphipods were also encountered in the same pools inside CN2 and are being identified.

Etymology. The species is named in honour of the renowned ornithologist and conservation biologist Dr. Ravi Sankaran, who pioneered cave studies in the Andaman and Nicobar Islands. He had first systematically documented the caves in the Andaman and Nicobar Islands while searching for populations of the cave-dwelling Ediblenest Swiftlet, A. fuciphagus Thunberg, 1812 and his dream and motivation led to the cave faunal study initiated in the Andaman Islands today.

Remarks. The present new species is closely related to Caridina typus H. Milne Edwards, 1837, Caridina villadolidi Blanco, 1939 and Caridina jeani Cai, 2010. It can be at once separated from others based on the characters given in Table 1. C. typus has been extensively studied by H. Milne Edwards (1837), Bouvier (1904; 1905; 1913; 1925), De Man (1892), Edmondson (1935), Holthuis (1960), Cai (2010). In C. typus and C. villadolidi the rostrum extends as far as the tip of $2^{\text {nd }}$ and $3^{\text {rd }}$ segments of the antennular peduncle, respectively. The present new species rostrum is shorter and extends only up to the distal end of the basal segment of the antennular peduncle. Moreover, the position of adrostral carina and disposition of teeth are characteristic to the species. Disto-median part of telson ends in a sharp point and with 4-5 (up to 9) spines with setae and two curved-in short spines at the distolateral end in C. typus, C. jeani and C. villadolidi, whereas in the present species, the telson doesn't end in a sharp point at disto-medial part and disto-lateral region with eight spines and without a pair of short spines; dorsal spines are distributed in the distal half in all the three species whereas in the present new species the proximal-most pair is at $1 / 3^{\text {rd }}$ distance from the base.

The middle segment of the antennular peduncle is longer than the distal segment in C. typus, whereas these segments are almost equal-sized in the present new species. The specimens of the new species possess a swollen basal part of the outer flagellum with 16 segments in the specimens studied and is characteristic.

The endopod of the second maxilliped has propodus and dactylus atrophied, and the nature of setation on it are characteristics to the species. In many species of Caridina reported from caves possess atrophied nature as above (Guo et al. 1992, Liang 1993, Liang and Zhou 1993, Cai and Li 1997, 1999, Cai and Ng 2018). First pair of chelate legs in which merus and carpus are equal-sized in C. typus, merus longer than carpus in C. villadolidi whereas in the present new species carpus is longer than merus. Fingers are nearly equal to palm or slightly shorter and bear very long bushy setae and are characteristic to the new species. In all the other three species, fingers are slightly longer with normal setae on fingers. Second chelate legs are slender in all species. Ischium is slightly longer than fingers in the present species, whereas it is shorter in other species. The merus is longer than propodus in the present species, C. jeani and C. villadolidi, whereas it is slightly shorter in C. typus. The fingers possess characteristically very long setae in contrast to other species. The number of spinules on the flexor side of propodi, dactyli vary in all the species under study. There is a considerable difference in the proportion of different segments of $5^{\text {th }}$ pereopod in all the species under study. In the present species, the dactylus possesses $42-43$ comb-like bristles similar to C. villadolidi and C. jeani whereas in C. typus it is 56-77. 
TABLE 1. Comparison of characters between Caridina ravisankarani sp. nov., C. typus H. M. Edwards, 1837; C. villadolidi Blanco, 1939 and C. jeani Cai, 2010.

\begin{tabular}{|c|c|c|c|}
\hline ukarani & $\begin{array}{l}\text { C. typus Н. М. Edwards, } \\
1837\end{array}$ & $\begin{array}{l}\text { C. villadolidi Blanco, } \\
1939\end{array}$ & C. jeani Cai, 2010 \\
\hline $\begin{array}{l}\text { Rostrum short, reaching as far } \\
\text { as the distal end of basal seg- } \\
\text { ment of antennular peduncle; } \\
\text { upper margin straight, without } \\
\text { teeth; ventral margin with } 2 \\
\text { minute teeth situated } 1 / 3 \text { rd } \\
\text { distal curved region }\end{array}$ & $\begin{array}{l}\text { Rostrum short, reaching as } \\
\text { far as middle segment to } \\
\text { slightly beyond the distal } \\
\text { end of antennular peduncle; } \\
\text { upper margin straight, with- } \\
\text { out teeth; ventral margin } \\
\text { with } 1-6 \text { (rarely } 7 \text { ) located } \\
\text { at distal } 2 / 3^{\text {rd }} \text { region. }\end{array}$ & $\begin{array}{l}\text { Rostrum moderately } \\
\text { long, reaching as far as } \\
\text { the distal end of antennal } \\
\text { scale, saber shaped; upper } \\
\text { margin straight without } \\
\text { teeth; ventral margin with } \\
2-8 \text { (usually } 3-5 \text { ), located } \\
\text { at distal } 2 / 3^{\text {rd }} \text { region. }\end{array}$ & $\begin{array}{l}\text { Rostrum short, reaching } \\
\text { up to or a little beyond } \\
\text { basal segment of antennu- } \\
\text { lar peduncle; upper margin } \\
\text { straight without teeth, } \\
\text { ventral margin with 1-5 } \\
\text { minute teeth situated at the } \\
\text { distal curved part }\end{array}$ \\
\hline $\begin{array}{l}\text { Dorsal surface of telson bears } \\
4-5 \text { pairs of sharp spines, proxi- } \\
\text { mal most pair at about } 1 / 3 \text { rd } \\
\text { distance from base, distal pair } \\
\text { near distal end, lateral margins } \\
\text { end in sharp points, disto-me- } \\
\text { dian region not pointed; outer } \\
\text { spines at posterior margin ab- }\end{array}$ & $\begin{array}{l}\text { Dorsal surface of telson } \\
\text { bears 5-6 (rarely 4) pairs } \\
\text { of spines distributed at pos- } \\
\text { terior half, lateral margins } \\
\text { somewhat produced, disto- } \\
\text { median region pointed; } \\
\text { outer spines of posterior } \\
\text { margin short, curved-in, dis- }\end{array}$ & $\begin{array}{l}\text { Dorsal surface of tel- } \\
\text { son bears 5-7 pairs of } \\
\text { spines, distributed evenly, } \\
\text { lateral margins do not end } \\
\text { in sharp points, disto-me- } \\
\text { dian region pointed; outer } \\
\text { spines of posterior margin } \\
\text { short, curved-in, distally }\end{array}$ & $\begin{array}{l}\text { Dorsal surface of telson } \\
\text { with } 5 \text { pairs of spines } \\
\text { distributed at distal half, } \\
\text { distal pair near distal end, } \\
\text { disto-median region } \\
\text { pointed; outer spines very } \\
\text { long, distally with 3-4 } \\
\text { pairs of spiniform setae }\end{array}$ \\
\hline
\end{tabular}
sent, distally with 8 spiniform setae of which lateral ones with setae only on inner side

Eyes with reduced pigmentation

Stylocerite of antennular peduncle reaches to 0.8 times the basal segment; basal region of outer flagellum swollen (16 segments), characteristic to the species

Endopod with propodus and dactylus of $2^{\text {nd }}$ maxilliped atrophied

$1^{\text {st }}$ pereopod: carpus longer than merus; propodus longer than carpus; fingers slightly shorter than palm; tally with maximum 9 short spiniform setae

Eyes with normal pigmentation

Stylocerite of antennular peduncle reaches to 0.8 times of basal segment; flagellae normal in size

Endopod of $2^{\text {nd }}$ maxilliped normal in shape

$1^{\text {st }}$ pereopod: carpus equals merus; propodus longer than carpus; fingers shorter than palm; fingers
Eyes with normal pigmentation

Stylocerite of antennular peduncle reaches distal end of basal segment; flagellae normal in size
Eyes with normal pigmentation

Stylocerite of antennular peduncle reaches 0.8 times of basal segment; flagellae normal in size
Endopod of $2^{\text {nd }}$ maxilliped normal in shape

$1^{\text {st }}$ pereopod: carpus shorter than merus; fingers longer than palm; fingers with short setae
Endopod of $2^{\text {nd }}$ maxilliped normal in shape

$1^{\text {st }}$ pereopod: carpus shorter than chela; fingers equal to or slightly shorter than palm; fingers with setae 


\begin{tabular}{|c|c|c|c|}
\hline ankarani sp. nov. & $\begin{array}{l}\text { C. typus H. М. Edwards, } \\
1837\end{array}$ & $\begin{array}{l}\text { C. villadolidi Blanco, } \\
1939\end{array}$ & C. jeani Cai, 2010 \\
\hline $\begin{array}{l}2^{\text {nd }} \text { pereopod: merus and carpus } \\
\text { longer than propodus; fingers } \\
\text { much longer than palm and with } \\
\text { very long tuft of setae at tips }\end{array}$ & $\begin{array}{l}2^{\text {nd }} \text { pereopod: merus sub- } \\
\text { equal to propodus; carpus } \\
\text { longer than propodus and } \\
\text { merus; fingers longer than } \\
\text { palm and with setae }\end{array}$ & $\begin{array}{l}2^{\text {nd }} \text { pereopod: merus } \\
\text { longer than propodus; fin- } \\
\text { gers longer than palm and } \\
\text { with setae }\end{array}$ & $\begin{array}{l}2^{\text {nd }} \text { pereopod: merus and } \\
\text { carpus a little longer than } \\
\text { propodus; fingers longer } \\
\text { than palm and with seate }\end{array}$ \\
\hline $\begin{array}{l}3^{\text {rd }} \text { pereopod: propodus with } 11 \\
\text { spinules on the mesial side; dac- } \\
\text { tylus ends in a claw and with } \\
4-5 \text { accessory spines on flexor } \\
\text { margin. }\end{array}$ & $\begin{array}{l}3^{\text {rd }} \text { pereopod: propodus with } \\
10 \text { spinules on mesial side; } \\
\text { dactylus ending in a claw and } \\
\text { with } 5-6 \text { (rarely } 3 \text { or } 4 \text { ) acces- } \\
\text { sory spines on flexor margin. }\end{array}$ & $\begin{array}{l}3^{\text {rd }} \text { pereopod; dactylus } \\
\text { ends in a claw and with } 7 \\
\text { accessory spines on flexor } \\
\text { margin. }\end{array}$ & $\begin{array}{l}3^{\text {rd }} \text { pereopod: propodus } \\
\text { with } 12 \text { spinules on the } \\
\text { mesial side; dactylus } \\
\text { ends in a claw with } 4 \text { acces- } \\
\text { sory spine on flexor margin }\end{array}$ \\
\hline $\begin{array}{l}\text { Dactylus of } 5^{\text {th }} \text { pereopods ends } \\
\text { in a sharp cruved spine and with } \\
42-43 \text { spinules }\end{array}$ & $\begin{array}{l}\text { Dactylus of } 5^{\text {th }} \text { pereopod } \\
\text { ends in a sharp curved spine } \\
\text { and with } 56-77 \text { spinules }\end{array}$ & $\begin{array}{l}\text { Dactylus of } 5^{\text {th }} \text { pereopod } \\
\text { ends in a sharp curved spine } \\
\text { and with } 44 \text { spinules }\end{array}$ & $\begin{array}{l}\text { Dactylus of } 5^{\text {th }} \text { pereopod } \\
\text { ends in a sharp curved spine } \\
\text { and with } 41-49 \text { spinules }\end{array}$ \\
\hline $\begin{array}{l}1^{\text {st }} \text { pleopod: basis of male with } \\
\text { stiff long setae at its tip, broader } \\
\text { and almost same length as exo- } \\
\text { pod; endopod half size of exopod } \\
\text { and with finger shaped appendix } \\
\text { interna }\end{array}$ & $\begin{array}{l}1^{\text {st }} \text { pleopod: basis of male } \\
\text { with stiff long setae at its } \\
\text { tip, broader and almost same } \\
\text { length as exopod; endopod } \\
1 / 4 \text { of exopod and with finger } \\
\text { shaped appendix interna }\end{array}$ & $\begin{array}{l}1^{\text {st }} \text { pleopod: endopod of } \\
\text { male bears finger shaped } \\
\text { appendix interna. }\end{array}$ & $\begin{array}{l}1^{\text {st }} \text { pleopod: endopod of } \\
\text { male appears bifid and } \\
\text { appendix interna slightly } \\
\text { beyond it }\end{array}$ \\
\hline $\begin{array}{l}\text { Diaeresis with } 18 \text { prominent } \\
\text { strong spines }\end{array}$ & $\begin{array}{l}\text { Diaeresis with } 20-23 \text { promi- } \\
\text { nent spines }\end{array}$ & $\begin{array}{l}\text { Diaeresis with } 16-22 \\
\text { spines }\end{array}$ & Dieresis with $17-19$ spines \\
\hline
\end{tabular}

The finger-shaped appendix interna in the present new species differs from the other three species. The diaeresis of the new species is with 18 prominent erect spines with a broad base, is within the range reported for $C$. jeani (17-19) and C. villadolidi (16-22) whereas C. typus possesses more number (20-23). Moreover, the eyes with reduced pigmentation is an adaptation in the cave environment.

From the foregoing discussion, it is evident that the species described herein deserves the merit to be elevated to a new species based on the difference in the rostrum, antennules and flagellae, mandible, $1^{\text {st }}$ maxilliped, $2^{\text {nd }}$ maxilliped, $3^{\text {rd }}$ maxilliped, bushy nature of setae on fingers and nature of different articles of the first pereopod, long nature of setae on fingers of the second pereopod, nature of spines on the flexor side of $3^{\text {rd }}$ and $4^{\text {th }}$ pereopods, number of bristles on the dactylus of $5^{\text {th }}$ pereopod, appendix interna on male first pleopod, the position of dorsal spines, distal spines and setae of telson, reduced eyes and habitat. General nature of rostrum of this species tends to retain similarity with species, namely, C. typus H. M. Edwards, 1837, C. zebra Short, 1993, C. confuse Choy \& Marshall, 1997, C. spinula Choy \& Marshall, 1997, C. nudirostris Choy, 1984, C. singhalensis Ortmann, 1894, C. imitatrix Holthuis, 1969, C. villadolidi Blanco, 1939 and C. jeani Cai, 2010.

Under the family Atyidae De Haan, 1849 (In De Haan, 1833-1850) several species have been reported stygobionts and it would be appropriate to mention them : Atyoida pilipes (Newport, 1847); Caridina cantonensis Yu, 1938; Caridina lovoensis Roth-Woltereck, 1955; Caridina troglophila Holthuis, 1965; Caridina troglodytes Holthuis, 1978; Caridina ablepsia Guo, Jiang and Zhang, 1992; Caridina guangxiensis Liang and Zhou, 1993; Caridina carvernicola Liang and Zhou, 1993; Caridina mengae Liang 1993; Caridina demenica Cai and Li, 1997; Caridina feixiana Cai and Liang, 1999; Caridina wumingensis Cai and NK Ng, 1999; Caridina caverna Liang, Chen and Li, 2005; Caridina acuta Liang, Chen and Li, 2005; Caridina alba Li and Li, 2010; Caridina longshan Cai and P K LNg, 2018; Caridina alu Cai and P K LNg, 2018; Caridina spinicrus Cai and P K LNg, 2018; Caridina beiliu Cai and P K LNg, 2018; Caridina jiangkou Cai and P K LNg, 2018; Caridina guilin Cai and P K LNg, 2018; 
Caridina laticarpalis Cai and P K LNg, 2018; Caridinopsis chevalieri Bouvier, 1912; Edoneus atheatus Holthuis, 1978; Edoneus erwini Cai \& Husana, 2009; Edoneus marulas Cai \& Husana, 2009; Edoneus sketi Cai \& Husana, 2009; Mancicaris sinensis Liang, Guo, and Tang, 1999; Neocaridina brevidactyla Liang, Chen and Li, 2005; Palaemonias alabamae Smalley, 1961; Palaemonias ganteri Hay, 1902; Parisia deharvengi Cai \& Ng, 2009; Parisia dentata Gurney, 1984; Parisia edentata Holthuis, 1956; Parisia gracilis Williams, 1964; Parisia macrophthalma Holthuis, 1956; Parisia microphthalma (Fage, 1946); Parisia unguis Williams, 1964; Stygiocaris lancifera Holthuis, 1960; Stygiocaris stylifera Holthuis, 1960; Troglocaris anophthalmaanophthalma (Kollar, 1848); Troglocaris anophthalma intermedia Babić, 1922; Troglocaris anophthalmalegovici Jugovic, Jalžić, Prevorčnik \& Sket, 2012; Troglocaris anophthalma ocellata Jugovic, Jalžić, Prevorčnik \& Sket, 2012; Troglocaris anophthalma periadriatica Jugovic, Jalžić, Prevorčnik \& Sket, 2012; Troglocaris anophthalma sontica Jugovic, Jalžić, Prevorčnik\&Sket, 2012; Troglocaris bosnica Sket \& Zakšek, 2009; Troglocaris planinensis Birstein, 1948; Typhlatya arfeae Jaume \& Bréhier, 2005; Typhlatya campecheae H. H. III Hobbs \& H.H. Jr. Hobbs, 1976; Typhlatya consobrina Botoşăneanu \& Holthuis, 1970; Typhlatya dzilamensis Alvarez, Iliffe \& Villalobos, 2005; Typhlatya elenae Juarrero, 1994; Typhlatya galapagensis Monod \& Cals, 1970; Typhlatya garciadebrasi Juarrero de Varona \& Ortiz, 2000; Typhlatya garciai Chace, 1942; Typhlatya iliffei Hart \& Manning, 1981; Typhlatya kakuki Alvarez, Iliffe \& Villalobos, 2005; Typhlatya miravetensis Sanz \&Platvoet, 1995; Typhlatya mitchelli H. H. III Hobbs \& H. H. Jr. Hobbs, 1976; Typhlatya monae Chace, 1954; Typhlatya pearsei Creaser, 1936; Typhlaty arogersi Chace \& Manning, 1972; Typhlatya taina Estrada \& Gómez, 1987; Typhlatya utilaensis Alvarez, Iliffe \& Villalobos, 2005; Typhlocaridina lanceifrons Liang and Yan, 1981; Typhlocaridina liui Liang and Zhou, 1993; Typhlocaridina semityhplata Cai, 1995; Xiphocaridinella ablaskiri Birstein, 1939; Xiphocaridinella dbari Marin, 2019; Xiphocaridinella fagei Birstein, 1939; Xiphocaridinella falcirostris Marin, 2020; Xiphocaridinella jusbaschjani Birstein, 1948; Xiphocaridinella kumistavi Marin, 2017; Xiphocaridinella kutaissiana Sadowsky, 1930; Xiphocaridinella motena Marin, 2019a; Xiphocaridinella osterloffi (Juzbaš’jan, 1941); Xiphocaridinella otapi Marin, 2018; Xiphocaridinella shurubumu Marin, 2018a; Xiphocaridinella smirnovi Marin, 2020. Caridina ravisankarani sp. nov. is a new addition to the species list.

Adaptations. Caridina ravisankarani sp. nov. possesses many adaptations in the cave environment, such as highly reduced pigmentation of eyes, atrophied propodus and dactylus of maxilliped 2, swollen segments of the outer antennular flagellum, more pediform pleopods, stronger ischium and merus of pereopods, and longer setae on all appendages as well as short closely set setae on mandibles. These adaptations help the animal to survive in the harsh environment of caves. These adaptations point towards it being a stygobite, a cave-dwelling aquatic species (Sket 2008). However, further intensive surveys are recommended to understand more about the species and its habitat.

\section{Acknowledgements}

The authors sincerely acknowledge the Ministry of Environment, Forest and Climate Change, Government of India for funding the project during this study's tenure. We thank the Andaman and Nicobar Forest Department for their active collaboration in the project and for providing permission to conduct the research. Our special thanks are due to the Wildlife Division, Mayabunder, for their support in carrying out the fieldwork. We extend special thanks to Dhanusha Kawalkar for her support during sample collection and Prathamesh Gurjarpadhye, Justin Sumit Kumar, Santial Toppo, and Saw Safarmi for their assistance during the fieldwork. Finally, we acknowledge Mutahir Mirza and Soham Dixit for their support in cleaning up the illustrations.

\section{References}

Alvarez, F., Iliffe, T.M., Villalobos, J.L. (2005) New species of the genus Typhlatya (Decapoda: Atyidae) from anchialine caves in Mexico, the Bahamas, and Honduras. Journal of Crustacean Biology, 25, 81-94. https://doi.org/10.1651/C-2516

Babic, K. (1922) Über die drei Atyidenaus Jugoslavien. Glasnik der Kroatischen Naturwissenschaftichen Gesellschaft, Zagreb, 34, 300-306.

Bandopadhyay, P.C. \& Carter, A. (2017) Introduction to the geography and geomorphology of the Andaman-Nicobar Islands. In: Bandopadhyay, P.C. \& Carter, A. (Eds.), The Andaman-Nicobar Accretionary Ridge: Geology, Tectonics and Hazards. Memoirs 47. Geological Society, London, pp. 9-18. 
https://doi.org/10.1144/M47.2

Botosaneanu, L. \& Holthuis, L.B. (1970) Subterranean shrimps from Cuba (Crustacea Decapoda Natantia). Travaux de l'Institut de Spéleologie "Emile Racovitza", 9, 121-133.

Blanco, G.J. (1939) Four new Philippine species of fresh-water shrimps of the genus Caridina. The Philippine Journal of Science, 70, 389-395.

Birstein, J.A. (1939) On the cave shrimps of Abkhazia. Zoologicheskii Zhurnal, 18, 960-975. [in Russian]

Birstein, J.A. (1948) The occurrence of the cave shrimp Troglocaris in underground water of Mazesta and related problems. Byulleten' Moskovskogo Obshchestva Ispytatelei Prirody, Otdel Biologicheskii, 53, 3-10. [in Russian]

Bouvier, E.L. (1904) Crevettes de la famille de Atyides: especies qui font partie de collections du Museum d'histoire naturelle. Bulletin du Muséum national d'histoire naturelle, 10, 129-138.

Bouvier, E.L. (1905) Observations nouvelles sur les Crevettes de la famille des Atyides. Bulletin scientifique de la France et de la Belgique, 39 (57), 134.

Bouvier, E.L. (1912) Un type nouveaux de crevette d'eaudouce africaine, la Caridinopsis Chevalieri nov. gen et sp. Bulletin du Muséum national d'Histoire naturelle, 1 (18), 300-303.

Bouvier, E.L. (1913) Les Caridines des Seychelles. The Percy Sladen Trust Expedition to the Indian Ocean in 1905, under the leadership of Mr. J. Stanley Gardiner. Transactions of the Linnean Society of London, Zoology, 2 (15), 447-472. https://doi. org/10.1111/j.1096-3642.1913.tb00113.x

Bouvier, E.L. (1925) Recherches sur la morphologie, les variations, la distribution géographique des crevettes de la famille des Atyidésséries A. 4. Encyclopédie Entomologique, Paris, 370 pp.

Cai, Y.X. (1995) A new troglobitic shrimp from China (Decapoda: Atyidae). Acta Zootaxonomica Sinica, 20, $157-160$.

Cai, Y. (2010) Caridina jeani, a replacement name for Caridina typus var. brevirostris J. Roux, 1911 from Eastern Indonesia (Crustacea: Decapoda: Atyidae). Zootaxa, 2372 (1) 80-84. https://doi.org/10.11646/zootaxa.2372.1.10

Cai, Y. \& Li, S. (1997) Caridina demenica, a new species of troglobitic shrimp (Crustacea: decapoda: Atyidae) from Guizhou, China. Raffles Bulletin of Zoology, 45, 315-318.

Cai, Y. \& Liang, X. (1999) Descriptions of three new species of freshwater shrimps (Crustacea: Decapoda; Atyidae) from Yunnan, southern China. Raffles Bulletin of Zoology, 47, 73-80.

Cai, Y. \& Ng, N.K. (1999) A revision of the Caridina serrata species group, with descriptions of five new species (Crustacea: Decapoda: Caridea: Atyidae). Journal of Natural History, 33, 1603-1638. https://doi.org/10.1080/002229399299789

Cai, Y. \& Ng, P.K.L. (2009) The freshwater shrimps of the genera Caridina and Parisia from karst caves of Sulawesi Selatan, Indonesia, with descriptions of three new species (Crustacea: Decapoda: Caridea: Atyidae). Journal of Natural History, 43, $1093-1114$. https://doi.org/10.1080/00222930902767482

Cai, Y. \& Ng, P.K.L. (2018) Freshwater shrimps from karst caves of southern China, with descriptions of seven new species and the identity of Typhlocaridina linyunensis Li and Luo, 2001 (Crustacea: Decapoda: Caridea). Zoological Studies, 57 (27), 1-33.

Cai, Y. \& Husana, D.E.M. (2009) Cave shrimps of the genus Edoneus Holthuis, 1978, from Luzon, the Philippines, with descriptions of three new species (Crustacea: Decapoda: Atyidae). Raffles Bulletin of Zoology, 57, 51-63.

Chace, F.A. Jr. (1942) A new cave shrimp from Cuba. Proceedings of the New England Zoölogical Club, 19, 99-102.

Chace, F.A. Jr. (1954) Two new subterranean shrimps (Decapoda: Caridea) from Florida and the West Indies, with a revised key to the American species. Journal of the Washington Academy of Sciences, 44, 318-324. https://doi.org/10.5479/si.00810282.131

Chace, F.A. Jr. \& Manning, R. B. (1972) Two new caridean shrimps, one representing a new family, from marine pools on Ascension Island (Crustacea: Decapoda: Natantia). Smithsonian Contributions to Zoology, 131, 1-18.

Choy, S. (1984) A New Atyid Shrimp, Caridina nudirostris sp. nov. (Decapoda, Natantia, Atyidae) from the Nadrau Plateau, Fiji. Crustaceana, 46 (3), 288-294. https://doi.org/10.1163/156854084X00207

Choy, S. \& Marshall, J. (1997) Two new species of freshwater atyid shrimps (Crustacea: Decapoda :Atyidae) from northern Queensland and the distributional ecology of the Caridina typus species-group in Australia. Memoirs of the Queensland Museum, 42 (1), 25-36.

Creaser, E.P. (1936) Crustaceans from Yucatan. In: Pearse, A.S., Creaser, E.P. \& Hall, F.G., The Cenotes of Yucatan. A Zoological and Hydrographic Survey. Carnegie Institution of Washington, Washington, pp. 117-132.

Culver, D.C. \& Pipan, T. (2009) The Biology of caves and other subterranean habitats. Oxford University Press, New York, New York, 24 pp.

De Haan, W. (1833-1850) Crustacea. In: von Siebold, P.F. (Ed.), Fauna Japonica sive Descripto Animalium, quae in Itinereper Japoniam, Jussu et Auspiciis Superiorum, qui Summum in India Batava Imperium Tenent, Suscepto, Annis 1823-1830 Collegit, Notris, Observationibus et Adumbrationibus Illustravit. Lugduni-Batavorum, Leiden, pp. i-xxxi $+\mathrm{ix}-\mathrm{xvi}+1-243$, pls. A-J + 1-Q + 1-55 + circ. Tab. 2.

de Man, J.G. (1892) Decapoden des Indischen Archipels. Zoologische Ergebnisseeiner Reise in Niederlandisch Ost-Indien, 2 , $265-527$.

de Man, J.G. (1908) On Caridina nilotica (Roux) and its varieties. Records of the Indian Museum, 2, $255-283$.

Edmondson, C.H. (1935) Atyidae of Southern Polynesia. B. P. Bishop Museum, Honolulu, Occasional Papers, 11 (3), 1-19.

Estrada, A.R. \& Gómez, O. (1987) Una nuevaespecie del géneroTyphlatya (Decapoda: Atyidae) de Cuba. Poeyana, 355, 1-12. 
Fage, L. (1946) Sur uneCaridine nouvelle cavernicole de Madagascar. Caridina microphthalma, nov. sp. Bulletin du Muséum national d'Histoire naturelle, 18 (2), 324-327.

Guo, Z., Jiang, H. \& Zhang, M. (1992) A new species of Caridina from Hunan, China (Decapoda: Atyidae). Sichuan Journal of Zoology, 11, 4-6. [in Chinese]

Gurney, A.R. (1984) Freshwater shrimp genera Caridina and Parisia (Decapoda: Caridea: Atyidae) of Madagascar, with descriptions of four new species. Journal of Natural History, 18, 567-590. https://doi.org/10.1080/00222938400770481

Hart, C.W.J. \& Manning, R.B. (1981) The cavernicolous caridean shrimps of Bermuda (Alpheidae, Hippolytidae, and Atyidae. Journal of Crustacean Biology, 1, 441-456. https://doi.org/10.2307/1547975

Hay, W.P. (1902) Observations on the crustacean fauna of the region about Mammoth Cave, Kentucky. Proceedings of the United States National Museum, 25, 223-236. https://doi.org/10.5479/si.00963801.25-1285.223

Hobbs, H.H. III \& Hobbs, Jr. H.H. (1976) On the troglobitic shrimps of the Yucatan Peninsula, Mexico (Decapoda: Atyidae and Palaemonidae). Smithsonian Contributions to Zoology, 40, 1-23. https://doi.org/10.5479/si.00810282.240

Holthuis, L.B. (1956) An enumeration of the Crustacea Decapoda Natantia inhabiting subterranean waters. Vie et Milieu, 7 , 43-76.

Holthuis, L.B. (1960) Two new species of atyid shrimps from subterranean waters of N.W. Australia (Decapoda Natantia). Crustaceana, 1, 47-57. https://doi.org/10.1163/156854060X00069

Holthuis, L.B. (1965) The Atyidae of Madagascar. Mémoires du Muséum national d'Histoire naturelle (A), Zoologie, 33, 148.

Holthuis, L.B. (1969) Études hydrobiologiquesen Nouvelle-Calédonie (Mission 1965 du premier Institut de Zoologie de l'Université de Vienne) (suite). IX: The freshwater shrimps (Crustacea Decapoda, Natantia) of New Caledonia. Cahiers O.R.S.T.O.M., série Hydrobiologique, 3, 87-108 [imprint 1969]

Holthuis, L.B. (1978) Zoological results of the British speleological expedition to Papua New Guinea 1975. 7. Cavernicolous shrimps (Crustacea Decapoda, Natantia) from New Ireland and the Philippines. Zoologische Mededelingen, 53, $209-224$.

Jaume, D. \& Bréhier, F. (2005) A new species of Typhlatya (Crustacea: Decapoda: Atyidae) from anchialine caves on the French Mediterranean coast. Zoological Journal of the Linnean Society, 144, 387-414. https://doi.org/10.1111/j.1096-3642.2005.00175.x

Juarrero, A. (1994) Nueva especie de camarón cavernícola (Decapoda: Atyidae: Typhlatya) de Cuba. Avicennia, 1, 57-66.

Juarrero de Varona, A. \& Ortiz, M. (2000) El género Typhlatya (Crustacea: decapoda: Atyidae) en Cuba, con la descripción de una nuevaespecie. Avicennia, 12/13, 45-54.

Jugovic, J., Jalžić, B., Prevorčnik, S. \& Sket, B. (2012) Cave shrimps Troglocaris s. str. (Dormitzer, 1853), taxonomic revision and description of new taxa after phylogenetic and morphometric studies. Zootaxa, 3421 (1), 1-31. https://doi.org/10.11646/zootaxa.3421.1.1

Juzbaš'jan, S.M. (1941) On the subspecies and intraspecific differentiation in Troglocaris kutaissiana Sadowsky. Communication I. Soobshcheniya Akademii Nauk Gruzinskoy SSR, 2 (10), 929-935. [in Russian]

Kawalkar, D. \& Manchi, S. (2020) Coastal caves on the Interview Island of Andaman Islands, India. Carbonates and Evaporates, $35,111$. https://doi.org/10.1007/s13146-020-00646-w

Kollar, V. (1848) Übereinneuessehrmerkwürdiges Crustaceumaus den unterirdischen Gewässern von Krain, welches Herr Custos H. Freyeran dask.k. Hof-Naturalien-Cabinet eingesendet hat. Sitzungsberichte der mathematisch-natur wissenschaftlichen Classe der Kaiserlichen Akademie der Wissenschaften in Wien, 1, 137-138.

Li, J.\& Li, S. (2010) Description of Caridina alba, a new species of blind atyid shrimp from Tenglongdong Cave, Hubei Province, China (Decapoda, Atyidae). Crustaceana, 83, 17-27. https://doi.org/10.1163/001121609X12530988607399

Liang, X. \& Chen, H. (2005) Three new species of atyid shrimps (Decapoda, Caridea) from caves of Guizhou, China. Acta Zootaxonomica Sinica, 30, 529-534.

Liang, X.Q., Z.L. Guo \& Tang, K.E. (1999) On new genus and species of atyid shrimps (Decapoda, Caridea) from Hunan, China. Journal of Fisheries of China, 23, 69-73.

Liang, X.Q. \& Yan, S-L, (1981) A new genus and two new species of freshwater prawns (Crustacea Decapoda) from Gunagxi, China. Acta Zootaxonomica Sinica, 6, 31-35.

Liang, X. \& Zhou, J. (1993) Study on new atyid shrimps (Decapoda, Caridea) from Guangxi, China. Acta Hydrobiologia Sinica, 17, 231-239. [in Chinese]

Liang, X. (1993) Two new species of Caridina from Guizhou, China (Crustacea: Decapoda). Acta Zootaxonomica Sinica, 18, $22-26$.

Manchi, S. (2014) Reassessment of the impact of nest collection on the Edible-nest Swiftlet in Andaman Islands. SACON Technical Report-126, Coimbatore. [unknown pagination]

Manchi, S. \& Sankaran, R. (2009) Impact of the 2004 earthquake on the limestone caves in North and Middle Andaman Islands. Current Science, 97 (8), 1230-1234.

Marin, I.N. (2017) Troglocaris (Xiphocaridinella) kumistavi sp. nov., a new species of stygobiotic atyid shrimp (Crustacea: Decapoda: Atyidae) from Kumistavi Cave, Imereti, Western Georgia, Caucasus. Zootaxa, 4311 (4), 576-588. 
https://doi.org/10.11646/zootaxa.4311.4.9

Marin, I.N. (2018) Cryptic diversity of stygobiotic shrimp genus Xiphocaridinella Sadowsky, 1930 (Crustacea: Decapoda: Atyidae): the first case of species co-occurrence in the same cave system in the Western Caucasus. Zootaxa, 4441 (2), $201-224$. https://doi.org/10.11646/zootaxa.4441.2.1

Marin, I.N. (2018a) Xiphocaridinella shurubumu sp. n. (Crustacea, Decapoda, Atyidae), a new stygobiotic atyid shrimp species from the Shurubumu and Mukhuri Caves, Chkhorotsku, western Georgia, Caucasus. Zoologicheskii Zhurnal, 97, 12381254. https://doi.org/10.1134/S0044513418100082

Marin, I.N. (2019) Crustacean "cave fishes" from the Arabika karst massif (Abkhazia, Western Caucasus): new species of stygobiotic crustacean genera Xiphocaridinella and Niphargus from the Gegskaya Cave and adjacent area. Arthropoda Selecta, 28 (2), 225-245.

https://doi.org/10.15298/arthsel.28.2.05

Marin, I.N. (2019a) A new stygobiotic Xiphocaridinella (Crustacea: Decapoda: Atyidae) from the Motena Cave, SamegreloZemoSvaneti region of Georgia, Caucasus. Zootaxa, 4648 (3), 592-600. https://doi.org/10.11646/zootaxa.4648.3.12

Marin, I.N. (2020) Stygobiotic atyid shrimps (Crustacea, Decapoda, Atyidae) from the Amtkel karst system, western Abkhazia, Caucasus, with a redescription of Xiphocaridinella osterloffi and the description of two new co-occurring species. Zoologicheskii Zhurnal, 99 (11), 1203-1222. https://doi.org/10.31857/S0044513420100128

Milne Edwards, H. (1834-1840) Histoire Naturelle des Crustacés, Comprenantl'Anatomie, la Physiologie et la Classification de ces Animaux. Encyclopédique Roret, Paris, III, 638 pp. https://doi.org/10.5962/bhl.title.6234

Monod, T. \& Cals, P. (1970) Sur uneespèce nouvelle de crevette cavernicole: Typhlatya galapagensis (Decapoda Natantia; Atyidae). Mission Zoologique Belge aux îles Galapagos et en Ecuador (N. et J. Leleup, 1964-1965), 2, 57-103.

Newport, G. (1847) Note on the genus Atya of Leach, with descriptions of four apparently new species, in the cabinets of the British Museum. The Annals and Magazine of Natural History, 19 (1), 158-160. https://doi.org/10.1080/037454809494502

Ortmann, A.E. (1894) Crustacean. In: R. Simon, ZoologischeForschungsreisen in Australien und demMalayischenArchipel. MitUnterstutzung des Herrn Dr Paul von Ritter ausgefuhrt in den Jahren 1891-1893. V. Denkschrift Medezenischnaturwissenschaften Gesellschaft Jena, 8, 3-80.

Roth-Woltereck, E. (1955) Vorläufige Mitteilungübereineneue Höhlengarneele (Decapoda Atyidae) aus Belgisch Kongo. Revue de Zoologie et Botanique Africaine, 51, 197-207.

Sadowsky, A.A. (1930) Xiphocaridinella kutaissiana nov. gen. et sp. (Fam. Atyidae) auseinerunterirdischen. Höhlebei Kutais Zakavkazskijkraevedstennysborniknaucnoissledovatel'nogokraevedstvenogokabineta Universiteta Tiflis, 1, 93-104. [in Russian]

Sankaran, R. (2001) The status and conservation of the Edible-nest Swiftlet (Collocalia fuciphaga) in the Andaman and Nicobar Islands. Biological Conservation, 97, 283-294. https://doi.org/10.1016/S0006-3207(00)00124-5

Sanz, S. \& Platvoet, D. (1995) New perspectives on the evolution of the genus Typhlatya (Crustacea, Decapoda): first record of a cavernicolous atyid in the Iberian Pensinsula, Typhlatya miravetensis n. sp. Contributions to Zoology, 65, 79-99. https://doi.org/10.1163/26660644-06502002

Short, J.W. (1993) Caridina zebra, a new species of freshwater atyid shrimp (Crustacea: Decapoda) from northeastern Queensland rainforest. Memoirs of the Queensland Museum, 34 (1), 61-67.

Sket, B. (2008) Can we agree on an ecological classification of subterranean animals? Journal of Natural History, 42 (21-22), $1549-1563$. https://doi.org/10.1080/00222930801995762

Sket, B. \& Zakšek, V. (2009) European cave shrimp species (Decapoda: Caridea: Atyidae), redefined after a phylogenetic study; redefinition of some taxa, a new genus and four new Troglocaris species. Zoological Journal of the Linnean Society, 155, 786-818. https://doi.org/10.1111/j.1096-3642.2008.00473.x

Smalley, A.E. (1961) A new cave shrimp from southeastern United States (Decapoda, Atyidae). Crustaceana, 3, $127-130$. https://doi.org/10.1163/156854061X00626

Tiwari, K.K. \& Pillai, S.R. (1971) Atyid Shrimps of the genus Caridina H. Milne Edwards, 1837, from the Andaman Islands (Decapoda, Caridea). Crustaceana, 21 (1), 79-91. https://doi.org/10.1163/156854071X00247

Thunber (1812) Remarks about the Swallows that build jelly-like, edible Nests. Kungliga Svenska Vetenskapsakademiens Handlingar, 1, 51-156.

Williams, W.D. (1964) Subterranean freshwater prawns (Crustacea: Decapoda: Atyidae) in Australia. Australian Journal of Marine and Freshwater Research, 15, 93-106. https://doi.org/10.1071/MF9640093

Yü, S.C. (1938) Studies on Chinese Caridina with descriptions of five new species. Bulletin of the Fan Memorial Institute of Biology, Zoology, 8, 275-310. 